lead to more equality, and that the fight against precarious work and for global standards always and everywhere needs the support of many allies.

Sibylle Marti

re:work, Humboldt-Universität zu Berlin Unter den Linden 6, I0099 Berlin, Germany

E-mail: sibylle.marti@fernuni-hagen.de doi:10.1017/S0020859020000607

\title{
Evans, Richard J. Eric Hobsbawm. A Life in History. Oxford University Press, New York [etc.] 2019. xiii, 785 pp. Ill. \$39.95.
}

Eric J. Hobsbawm was the most famous historian of the second half of the twentieth centuryperhaps not in terms of his significance in any single country or language sphere, yet arguably as somebody read in all major world regions and across many languages. It is thus no surprise that the first major biography of Hobsbawm - historians' biographies normally being a subgenre of little appeal to a wider audience - was delivered by a prominent historian himself and has garnered both wide attention and acclaim. And, indeed, it is a profoundly well-researched treasure trove for anybody interested in the history of historiography, the rise of social history, and the intellectual history of the left in the twentieth century. At more than 700 pages, it offers readers a detailed record of a truly wide-ranging life. It is both magisterial and, in many ways, invites debate and criticism.

Many moments and facets of Hobsbawm's life are well-known, not least because of his bestselling autobiography Interesting Times (2002). These include his Jewish-Viennese background, his adolescent years in Berlin, his move to England, his membership of the Communist Party (which, unlike many others, he did not quit after 1956), his writing ambitions and skills, his role in the rise of social history, his interest in cultural phenomena, social outsiders, and marginal rebels, his ability to trigger central debates, his "parallel life" as a jazz columnist, and his role as a grand-panorama historian of modernity, artfully mixing argument, analysis, and narrative sweep.

Evans's aim is not to compete with Interesting Times, but to complement it. He had full access to the papers from Hobsbawm's estate. These, together with interviews and other abundant archival material (including declassified intelligence reports), allow for an extraordinarily detailed reconstruction of Hobsbawm's doings and feelings. Evans makes use of this rich mountain of material in a way that would have been to the liking of his hero: a fully "materialist" rendering of the intellectual as a mythical figure of modernity. Evans highlights the degree to which the work of a professional thinker, writer, and teacher is dependent on their ability to generate income, on institutional support (and obstruction), on the available media for communication (Hobsbawm's career being partly contingent on the paperback revolution), on living arrangements, particularly housing, and not least on their emotional well-being. In that sense, Evans's minute reconstruction of Hobsbawm's crisis when his first marriage came to an end, as well as his longer and shorter relationships subsequently, some of them non-standard, does not appear glib but shows how essential this well-being was to allowing Hobsbawm to work. This real-life-embeddedness, moreover, does not include much information on the pressing questions of reproduction - eating, drinking, 
cleaning, clothing, care, etc. As becomes clear in the chapters about his family life with Marlene Schwarz after he remarried in 1962, Hobsbawm still had the privilege of experiencing fatherhood without having to trouble himself too much with the Herculean task of combining this unpaid work with intellectual labour - a fact that somehow parallels the criticism of gender blindness voiced repeatedly about his landmark books.

As much materiality of life is laid bare and previously unknown facts are unearthed through the extensive use of Hobsbawm's papers - diaries, letters, notes - this also produces some quaint imbalances and distorting effects. Readers must wade through 350 pages before they get to 1956, when the Communist Party Historians Group dissolved under pressure from the crisis unleashed by the Soviet invasion of Hungary and most of its members leaving the party. Hobsbawm, then aged thirty-nine, decided to stay (as he did later, in I968). This extensiveness does not, however, include much contextual background (sometimes sketched just lightly), nor is it always inserted into or does it reference the research literature (readers of the history of communisms will be particularly irritated by the incomplete linkage here); it is mainly the result of paraphrases and direct quotes from Hobsbawm's thoughts and impressions. Evans refers readers to Hobsbawm's autobiography for some of this contextual information, focusing his account "above all on his personal experiences and indeed his inner life" (p. ix). Still, although I count myself among the "category I" readers of this biography (eagerly interested in the subject with an appetite for curious details), I had to flinch sometimes when yet another page-long summary of a trip to France and other countries came up. As joyful an indulgence in abundant material may be, it can also be a curse.

Evans's biography is finely structured, with each sub-chapter dedicated to a specific experience in Hobsbawm's life, propelled forward by his book publications, their origins, and the debates they unleashed. Yet, while it seems more than commendable to reconstruct Hobsbawm's arguments from the acclaim and critique of his reviewers, Hobsbawm's ideas get surprisingly little coverage (sometimes it is little more than a blurb). This is not the kind of intellectual biography that offers readers a comprehensive summary of the opus of its subject.

Meanwhile, Evans's focus on interactions instead of ideas enables him to canvass the vast mesh of both intellectual and personal contacts that grew around Hobsbawm. This kind of implicit network analysis gives a proper sense of how Hobsbawm created a sphere in which communisms of several, though not all, variants as well as other left-wing persuasions intermingled and how these could be brought in touch with historiographical research. Particularly when talking about the years after 1956, Evans contributes to a growing body of research that questions too strict a boundary between the "old" and "New Left" (at least in intellectual terms) and points to the many interrelations between them. Hobsbawm - the pragmatic communist, the dissident within his camp who was only grudgingly tolerated by the CPGB party apparatus - is without doubt a prime example of this porousness of spheres. At the same time, Evans tends to overstretch his point and to project Hobsbawm's self-fashioned image of a communist insider-outsider who acts as ambassador of a broad-left ethos onto historical constellations that contemporaries experienced as a rift extending deep and far. As Bryan D. Palmer pointed out in a recent extended review, ${ }^{\mathrm{I}}$ Evans is imprecise in writing that, between Hobsbawm and E.P. Thompson, John Saville, Rodney Hilton, and many others there were, as Evans claims, "no real political differences beyond

I. Bryan D. Palmer, “Hobsbawm's Century”, Catalyst, 4:I (2020), pp. 60-100, available at: https://catalyst-journal.com/vol4/nor/hobsbawms-century; last accessed 6 September 2020. 
the merely symbolic one of membership in the Party" (p. $35 \mathrm{I}$ ). And while Hobsbawm had a keen interest in and warm openness for "primitive rebels", Latin American guerrilla fighters, and a number of currents of the left that had been discarded by mainstream labour movements, he remained coldly condescending of important other currents, particularly those forms of dissident communism that had already emerged in the interwar period. Evans echoes this selectiveness in the broad-left ethos of Hobsbawm. True, such issues are directly political, and Evans makes it clear in the introduction that, while having written this biography with great sympathy for Hobsbawm, he considers himself a "social democrat" (p. ix). Yet, this affects how the person emerges after 700 pages: Evans is consistently understanding of Hobsbawm's pragmatic realism, for instance in relation to the manifold turns of Stalinist politics from the I930s onwards, or his decision to stay in the Communist Party after 1956 and 1968. And Evans particularly appreciates the Hobsbawm who, during the i980s, after publishing the essay "The Forward March of Labour Halted" (1978), became an intellectual catalyst of the defeat of the left within the Labour Party (something for which many left-wing intellectuals never forgave him). At the same time, he reveals a sense of foreignness when it comes to those moments when Hobsbawm appears as a genuine radical of left-wing persuasion: his decision to become a communist in the first place; his unapologetic defence, even after 1989, of "revolution" as necessary and justified; or his general vindication of a continued relevance of the notion of "socialism".

Finally, there is the issue of biography after the "global turn" and all the heady talk of "transnational biographies" and "entangled lives". Evans, as an acclaimed historian of Germany's history, is certainly aware of such non-parochial perspectives. Indeed, he does not tire of highlighting Hobsbawm's bicultural mindset, his polyglot cosmopolitanism, his vast international network, and the importance of his travels abroad. Also, it is refreshing to read about the condescension with which Hobsbawm regarded the narrow-minded parochialism of interwar Cambridge and the limitedness of England's intellectual culture, which was not up to what he had experienced as a German-language Bildungsbürgertum.

Yet, despite all that, Hobsbawm, as rendered by Evans, largely appears as an Englishman. Without doubt, he was that, too. The point, however, is that for many people around the world he was something beyond that. This refers to two more fundamental problems of biographical writing after the "global turn". Firstly, how far to go in reconstructing the networks of such a widely connected person in sensu stricto. To give a random example: I recently had the honour of reviewing a biography of Franz Marek, an Austrian communist and intellectual who morphed from a Stalinist party functionary into an internal dissident, quitting the party after the suppression of the Prague Spring and becoming the editor of a broad-left, increasingly Eurocommunist intellectual journal. Admittedly, unless you are specializing in the history of Central European communist movements or the history of Eurocommunism, you can be forgiven for not knowing this figure. However, the authors of the biography insistently advertise the friendly exchanges and proximity between Marek and Hobsbawm and the latter's endorsement of the political platform embodied by the journal Wiener Tagebuch. ${ }^{2}$ Evans does not mention this relationship at all. Certainly, Evans had to be selective in his material, particularly in what is already an extensive biography, yet equally certainly there will be hundreds of international contacts and exchanges that informed readers from different countries will look for in vain.

2. Maximilian Graf et al., Franz Marek. Ein europäischer Marxist. Die Biografie (Vienna, 2019). 
Secondly, how to reconstruct the global Eric Hobsbawm in a wider sense - an author with the singular ability to become a point of reference not only for general readers, but also for several generations of historians, not least in the countries of the Global South. ${ }^{3}$ Twenty years after the "global turn", it has a strange effect of unintended centredness to see Hobsbawm's major books come alive through the contemporary reviews of others, yet almost entirely by anglophone authors, while the numerous translations are duly mentioned, but only as a list. To see Hobsbawm's "Life in History" in full, a second biography might therefore be needed, one that focuses on the global figure in all its facets of contacts, impacts, and appropriations. Such an enterprise can probably only be done collectively - and one can only hope that it will be as thoughtful and elegant as Evans's first foray.

David Mayer

University of Vienna, Institut für Wirtschafts- und Sozialgeschichte

Universitätsring I, Iо I० Vienna, Austria david.mayer@univie.ac.at

doi:10.1017/S0020859020000619

An Economic History of Famine Resilience. Ed. by Jessica Dijkman and Bas van Leeuwen. [Routledge Explorations in Economic History, 84.] Routledge,

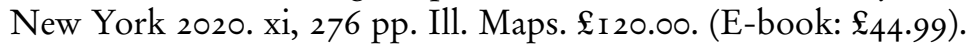

This highly interesting volume originated in a workshop organized in Utrecht, the Netherlands, in November 2016. The editors' selection follows a global approach in a very long-run perspective. The result is an impressive fresco of the socioeconomic and institutional practices promoted in different places and times to cope with famine, which endeavours to lay bare the reasons for the success or failure of such practices in different cases. What remains less clear are the case-selection criteria and whether they can be considered strictly comparable.

In their exhaustive introduction (pp. I-I3), Jessica Dijkman and Bas van Leeuwen outline the central issue, the theories and concepts, the different actors, and some general patterns that form the basis of this book, which they say discusses the "societal resilience to food crises and famines: the responses and strategies at the societal level that effectively helped individuals and groups to cope with drops in food supply, in various parts of the world over the past two millennia" (p. I). Famine is considered here as the combined outcome of human and natural factors, with a central role being played by institutions in promoting the distribution of food. This volume therefore focuses particularly on "the three main coordination mechanisms that, in any society, allow people to allocate or share resources: the state, the market, and civil society" (p. 2), and on how they react to food crises, by promoting social (or, better, famine) resilience. In the last part of the introduction, through the great heterogeneity of forms and practices of famine resilience described in the various chapters, the

3. For an essay on the "global Hobsbawm", see Emile Chabal, "The Voice of Hobsbawm: How the Marxist Ideas of a British Historian Ended up on the Bookshelves of Indian Civil Servants and Brazilian Housewives", Aeon, available at: https://aeon.co/essays/how-eric-hobsbawm-helpedshape-the-global-marxist-imagination; last accessed 6 September 2020. 